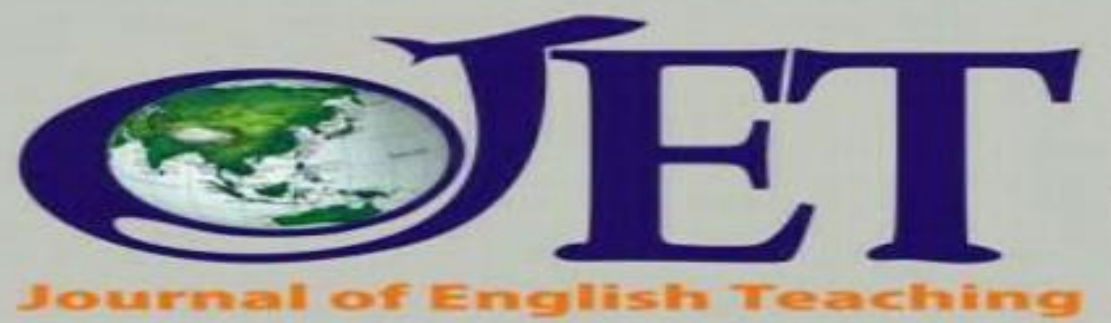

ISSN 20809628

a

triannual

publication

on the study of

English L anguage Teaching

Volume 3 Number 1, February 2017

\title{
Students' Perception on the Discovery Learning Strategy on Learning Reading Comprehension at the English Teaching Study Program, Christian University of Indonesia
}

\author{
Daniel Tampubolon \\ danielgrg51251@gmail.com \\ Universitas Kristen Indonesia
}

\begin{abstract}
The main objectives of this study are to discover and examine the students' perception on the use of discovery learning strategy on reading comprehension and to see whether the students are interested in using discovery learning strategy on improving their reading comprehension. This study is a survey research. This study was conducted to all students of the English Teaching Study Program (ETSP), Christian University of Indonesia. To achieve the objectives, data were collected using questionnaire and interviews. The data was analyzed descriptively through Microsoft Excel 2007. Based on the data analysis, it can be concluded that the majority of students agreed that discovery learning strategy can enhance their reading comprehension and they want this strategy implemented in their reading class. Furthermore, they were interested on learning or improving reading comprehension through discovery learning strategy.
\end{abstract}

Keywords: reading comprehension, discovery learning strategy, perception

\section{Introduction}

Reading is a linguistic process in which the readers search information or the message that were written. Reading, as one of the important skills in acquiring new language functions as a way for the learners to get new information. Tarigan (1987) defined that reading is a process that is carried and used by the reader to get information and message. The solid definitions came from Cameroon (2001) stated that reading is actually about understanding, not only understand the word or code but also the message 
Tampubolon, Students' Perception on the Discovery Learning Strategy on Learning Reading Comprehension

being conveyed. Also, Grabe \&Stoller (2013, p. 3) defined it as an ability to draw meaning from the printed page and interpret the information appropriately. These definition imply that reading is not a passive process, but an active one. Pardede (2007), argued that current theories view reading as a process of not just extracting meaning from a text but a process of connecting information in the text with the knowledge the reader brings to the act of reading. Reading, in this sense, is "a dialogue between the reader and the text" (Grabe, 1988, p. 56).

Reading comprehension is not a passive process, but an active one. According to Pardede (2007), current theories view reading as a process of not just extracting meaning from a text but a process of connecting information in the text with the knowledge the reader brings to the act of reading. Reading, in this sense, is "a dialogue between the reader and the text" (Grabe, 1988, p. 56).

By reading, learners can also enrich their vocabulary, improve their pronunciation and develop their grammar. It means reading is very important to be mastered by the students. Due to its importance in language learning, reading is probably the most extensively and intensively studied skills in the field of language teaching (Pardede, 2008). Larsen-Freeman (1990, p. 1) stated that the secret of effective teaching and learning reading is due to the effort or strategy that is made by the language instructors or the teacher in the classroom. Therefore, the role of the teacher is important to help the students enhance their reading comprehension, although there will be barriers that are faced by the teacher.

Generally, the problem may come from the teacher and students. Based on the researcher's observation at ETSP of UKI, it was found that the problem that is faced by the teachers is the lack of strategy in teaching reading. For example, they do not have a strategic way to relate the topic being taught with the students' real world. Meanwhile, the problems from the students' side on learning reading was due to the students' lack of background knowledge such as related idea, linguistic elements and the structure of the text. It makes the students could not comprehend the text because of many difficult words. For example, the students preferred not to continue reading a text or book since the whole meaning of the text was determined by those unknown words. They would rather stop reading and asking the other friends about the information presented. 
Tampubolon, Students' Perception on the Discovery Learning Strategy on Learning Reading Comprehension

To solve those problems, there are many strategies indeed have been conducted to improve students' reading comprehension. Such as, problem-based learning, task-based learning, and discovery learning strategy. Through this paper, the researcher only focused on the discovery learning strategy (DLS).Based on the literature review, Bruner (2006) regarded that discovery learning agreed with searching knowledge actively by a human being and automatically gave the best result in this strategy. Rahmi and Ratmanida (2014) explained that "discovery learning strategy is a strategy in which the students are not given the content of the lesson in the beginning of study, but they have to find it by themselves". Furthermore, Saritas (2005, p. 54) who believed that the process of discovery learning strategy in reading class is the activities in which there are many opportunities for learners to use and share knowledge in solving problem. In parallel with Balim (2009, p. 2) revealed that "discovery learning is a method that encourages the students to arrive at a conclusion based upon their own activities and observations". Meanwhile, Hammer (1997, p. 485) also considered that discovery learning is a process of learning which encourages the students to arrive at a conclusion based upon their own activities and observations. In addition, Mahmoud (2014) had conducted discovery learning strategy to improve students' English skill. He believed that this strategy is a good way to improve language skill. In accordance with these definitions above, the researcher views that this learning strategy can help the teacher to achieve the goals of learning reading. The researcher summarized that there are attributes of the discovery learning strategy. Bicknell-Holmes and Hoffman (2000) described three main attributes: (a) exploring and problem solving are to create, integrate, and generalize knowledge; (b) student-driven, interest-based activities in which the student determines the sequence and frequency, and (c) activities to encourage the integration of new knowledge into the learner's existing knowledge base.

The first attribute of discovery learning is a very important one. Through exploring and problem solving, the students take on an active role to create, integrate, and generalize knowledge. Instead of engaging in passively accepting information through lecture or drill and practice, the students establish broader applications for skills through activities that encourage risk-taking, problem-solving, and an examination of unique experiences. In this attribute, the students rather than the teacher drive the learning. Expression of this attribute of discovery learning essentially changes the roles of the students and the 
Tampubolon, Students' Perception on the Discovery Learning Strategy on Learning Reading Comprehension

teachers. The second attribute of discovery learning is that it encourages the students to learn at their own steps. Through discovery learning, the students' interest will be increased in learning activities and the goals of learning can be achieved. This attribute contributes greatly to the students' motivation and ownership of their learning. The third attribute of discovery learning is that it is based on the principle of using existing knowledge as a basis to build new knowledge. Scenarios with which the students are familiar allow the students to build on their existing knowledge by extending what they already know to invent new ideas.

In accordance with the experts' opinions above, it can be interpreted that the students will be independent learners and not rely on the teachers' instruction and command any longer. Discovery learning strategy creates an active learning process in which the material or the contents of the topic are not given by the teacher at the beginning of the lesson directly. During the process of this strategy, the students are asked to be able to find the way how to solve the problems by themselves.

As such all definitions above, the researcher would like to know the students' perception about this strategy toward reading comprehension. Therefore, the researcher is very much interested in conducting this study to find out and investigate the students' perception on the use of discovery learning strategy on learning reading comprehension at the English Teaching Study Program, Christian University of Indonesia.

\section{Methodology}

This study was conducted at the English Teaching Study Program, Christian University of Indonesia on April-July 2016 to measure the students' perception on the use of discovery learning strategy on learning reading comprehension. The respondents were only 81 students. All of the students were administered a questionnaire. The questionnaire itself was divided into two major sections. The first section collected the students' demographic variables; namely gender and semester. The second section of the questionnaire measures the students' perception on the use of discovery learning strategy on learning reading comprehension. For the interview, a focused semi structured openended interview was employed. The interview was carried out byinviting 4 students who were selected randomly from each semester. The interview questions were basically 
Tampubolon, Students' Perception on the Discovery Learning Strategy on Learning Reading Comprehension

similar to the one question written on the questionnaires. The interview took about thirty minutes.

To guarantee the validity of the qualitative data obtained in this study, the researcher conducted 3 data triangulation. First, methodological triangulation was employed by using the questionnaire and interview to collect qualitative data. Second, the theoretical triangulation was employed by using more than one theory to interpret the data and to design the items of indicators based on the concepts. Third, investigator triangulation, referred to the use of experts' perspective in interpreting the data.

\section{Result and Discussion}

The twenty-four items included in the questionnaire can be divided into four indicators. The first indicator is "the Benefits on Using the Discovery Learning". The next indicator is "the Interest in Using the Discovery Learning". The third indicator is "the Activities of the Discovery Learning". The last indicator is "the Implementation of the Discovery Learning". The findings related to the respondents' perceptions toward the benefits of discovery learning strategy (as shown in table 1) revealed that around of $69 \%$ of students agreed and strongly agreed that discovery learning strategy improved their curiosity to find some information from book or text and around of $61 \%$ of students agreed and strongly agreed discovery learning strategy can construct their reading comprehension, but $14 \%$ of them disagreed and strongly disagreed. It is strengthened by finding that $66 \%$ of the students agreed and strongly agreed then $14 \%$ strongly disagreed and disagreed that using discovery learning strategy can motivate them to enhance reading comprehension and $16 \%$ of students disagreed and strongly disagreed that discovery learning strategy can make them tobe more serious in learning reading. However, 55\% of students agreed and strongly agreed that discovery learning strategy can make them to be more serious in learning reading. It seems the majority of students believe that discovery learning strategy could motivate them to improve reading comprehension. It is supported by finding data, $63 \%$ of them agreed and strongly agreed that discovery learning strategy can improve theircritical reading, $64 \%$ of them agreed and strongly agreed that discovery learning strategy can help them to developtheir pronunciation, 65\% agreed and strongly agreed that discovery learning strategy can improve their grammar, and $78 \%$ of students agreed 
Tampubolon, Students' Perception on the Discovery Learning Strategy on Learning Reading Comprehension

and strongly agreed discovery learning strategy helps them to improve their vocabulary. (see Table 1)

Table 1

Students' Perception toward the Benefit of Discovery Learning

\begin{tabular}{|c|c|c|c|c|c|c|c|c|c|c|c|}
\hline \multirow{2}{*}{ No } & \multirow{2}{*}{ Statements } & \multicolumn{2}{|c|}{ SD } & \multicolumn{2}{|c|}{$\mathbf{D}$} & \multicolumn{2}{|c|}{$\mathbf{N}$} & \multicolumn{2}{|c|}{$\mathbf{A}$} & \multicolumn{2}{|c|}{$\mathbf{S A}$} \\
\hline & & $\mathbf{f}$ & $\%$ & $\mathbf{f}$ & $\%$ & $\mathbf{f}$ & $\%$ & $\mathbf{f}$ & $\%$ & $\mathbf{f}$ & $\%$ \\
\hline 1 & $\begin{array}{l}\text { Increases my curiosity to } \\
\text { find some information from book }\end{array}$ & 3 & 4 & 4 & 5 & 18 & 22 & 46 & 57 & 10 & 12 \\
\hline 2 & $\begin{array}{l}\text { Help to find some vocabularies by } \\
\text { reading a book/text }\end{array}$ & 5 & 6 & 5 & 6 & 8 & 10 & 55 & 68 & 8 & 10 \\
\hline 3 & Developing grammar comprehension & 3 & 4 & 4 & 5 & 21 & 26 & 40 & 49 & 13 & 16 \\
\hline 4 & $\begin{array}{l}\text { Improving my pronunciation/ } \\
\text { fluency in reading a text/book }\end{array}$ & 5 & 6 & 4 & 5 & 20 & 25 & 42 & 52 & 10 & 12 \\
\hline 5 & Improving my critical reading & 3 & 4 & 3 & 4 & 24 & 30 & 40 & 49 & 11 & 14 \\
\hline 6 & $\begin{array}{l}\text { Motivating to improve my reading } \\
\text { comprehension. }\end{array}$ & 3 & 4 & 8 & 10 & 17 & 21 & 41 & 51 & 12 & 15 \\
\hline 7 & $\begin{array}{l}\text { Constructing reading comprehension } \\
\text { using discovery learning strategy }\end{array}$ & 4 & 5 & 7 & 9 & 20 & 25 & 48 & 59 & 2 & 2 \\
\hline 8 & Making me to be more serious & 4 & 5 & 9 & 11 & 23 & 28 & 39 & 48 & 6 & 7 \\
\hline
\end{tabular}

Yes, of course, because I tink if the teachers apply this strategy, it can helpthe students improve their reading ability. (Interviewee A)

Yes of course, because when students discover the knowledge the students will be motivated to improve the ability of reading and it means discovery learning strategy makes the students' motivation improved. (Interviewee B)

For myself, discovery learning motivates me to improve my reading comprehension. Because through discovery learning, I feel challenged to read a lot of books, search the material if I do not understand and answer the question. So, it directly gives me the motivation to improve my reading comprehension. (Interviewee C)

I think it is motivating me to improve my reading comprehension. Because become like reading a book and I' $m$ appreciating when the teacher asks me to search material or answer from the book. (Interviewee D) 
Tampubolon, Students' Perception on the Discovery Learning Strategy on Learning Reading Comprehension

The findings of the students' perception of the interest in using discovery learning strategy on reading comprehension indicates that the majority of their view of using discovery learning strategy is high. Most of the students $56 \%$ up to $68 \%$ agreed and strongly agreed that students are interested in using discovery learning on improving reading comprehension. It means, based on the responses, most of the students are interested in using discovery learning strategy to improve their reading comprehension. However, there were a few students who are not interesting in using discovery learning strategy on reading comprehension. $11 \%$ up to $19 \%$ disagreed and strongly disagreed that discovery learning is an interesting strategy to develop reading comprehension. There were $58 \%$ of them agreed and strongly agreed if they are assigned by the teacher to find information. In sharing and telling findings to friend, there were $65 \%$ students agreed and strongly agreed. Meanwhile, there were $63 \%$ of them agreed and strongly agreed that they like to deliver a presentation in front of the class. There were $68 \%$ of them an interest in making a group for discussion and this item is the highest percentage of the interest in using the discovery learning strategy on reading comprehension. The lowest percentage is $46 \%$ of them agreed and strongly agreed that they like to discover something new by their own. (See Table 3)The data obtained through interviews strengthened these findings, as indicated in the following excerpts.

Yes, I like, I think because the students have to practice or share the information what they comprehend or get from a book, so the teacher has to give a chance to the students in order to improve their ability. (Interviewee A)

Yes, I like learning reading if the teacher gives a chance for students to share their finding to the friends from books/ text. Because when students share each other their finding, it can help other students to be more understand the material.

(Interviewee B) 
Tampubolon, Students' Perception on the Discovery Learning Strategy on Learning Reading Comprehension

Table 2

Students' Perception of the Interest in Using the Discovery Learning

\begin{tabular}{|c|c|c|c|c|c|c|c|c|c|c|c|}
\hline \multirow{2}{*}{$\begin{array}{l}\mathbf{N} \\
\mathbf{0}\end{array}$} & \multirow{2}{*}{ Statements } & \multicolumn{2}{|c|}{ SD } & \multicolumn{2}{|c|}{ D } & \multicolumn{2}{|c|}{$\mathbf{N}$} & \multicolumn{2}{|c|}{$\mathbf{A}$} & \multicolumn{2}{|c|}{$\mathbf{S A}$} \\
\hline & & $\mathbf{f}$ & $\%$ & $\mathbf{f}$ & $\%$ & f & $\%$ & $\mathbf{f}$ & $\%$ & f & $\%$ \\
\hline 1. & $\begin{array}{l}\text { Assigned to find some } \\
\text { information by reading } \\
\text { a book/text. }\end{array}$ & 5 & 6 & 4 & 5 & 25 & 31 & 38 & 47 & 9 & 11 \\
\hline 2. & $\begin{array}{l}\text { Sharing finding from a } \\
\text { text/ book and telling it } \\
\text { to my friends during } \\
\text { the lesson. }\end{array}$ & 5 & 6 & 6 & 7 & 18 & 22 & 45 & 56 & 7 & 9 \\
\hline 3. & $\begin{array}{l}\text { Delivering my findings } \\
\text { from a text/ book } \\
\text { through presentation }\end{array}$ & 3 & 4 & 8 & 10 & 19 & 23 & 40 & 49 & 11 & 14 \\
\hline 4. & $\begin{array}{l}\text { Interest inmaking } \\
\text { groups for discussion } \\
\text { with my friends in } \\
\text { learning reading }\end{array}$ & 3 & 4 & 12 & 15 & 11 & 14 & 39 & 48 & 16 & 20 \\
\hline 5. & $\begin{array}{l}\text { Interest in discovering } \\
\text { something new in } \\
\text { book/text on my own }\end{array}$ & 3 & 4 & 9 & 11 & 24 & 30 & 37 & 46 & 8 & 10 \\
\hline
\end{tabular}

The distribution of the students' perception of the activities on the discovery learning strategy in reading comprehension show that $56 \%$ of the students agreed and strongly agreed that it is helpful if the teacher assigns students to find and use techniques in reading a book. However, $19 \%$ of them disagreed and strongly disagreed. On the other hand, $17 \%$ of them disagreed and strongly disagreed and $52 \%$ of them agreed and strongly agreed that they like to conclude an idea after reading a book. In the item of learning reading by making a group, $63 \%$ of them agreed and strongly agreed but only $20 \%$ of the students disagreed and strongly disagreed. $63 \%$ of them agreed and strongly agreed that they like if the teacher gives a chance for students to share something to their friends and only $6 \%$ of them disagreed and strongly disagreed.

In the item of activities of sharing information from text, $62 \%$ of them like to share information from text to their friends. $65 \%$ of them agreed and strongly agreed that they like to collect some words or sentences which they do not understand from text or book. In the item of answering questions in book, 53\% of them agreed and strongly agreed, however, $18 \%$ of them disagreed and strongly disagreed (see Table 3 ). These findings proved that there were a large number of students who agreed and enjoyed the activity of the discovery learning strategy in reading comprehension. The findings were supported 
Tampubolon, Students' Perception on the Discovery Learning Strategy on Learning Reading Comprehension

by the interview data. It is obtained from interview (semi-structured open-ended interview) have shown students' perception, as below:

It is very helpful, because if the teacher assigns the students to find the reading techniques, it makes the students more active and exactly it can make the students understand very well about the reading techniques rather than teacher explained to me by the teacher. ( Interviewee $A$ )

Yes, it is helpful, because when the teacher assigns the students to find and use reading techniques, the students will be an active learner. In this case, the students are able to use reading techniques and find it by themselves and understand it.

(Interviewee B)

Table 3

Students' Perception of the Activities on the Discovery Learning

\begin{tabular}{|c|c|c|c|c|c|c|c|c|c|c|c|}
\hline \multirow{2}{*}{ No } & \multirow{2}{*}{ Statements } & \multicolumn{2}{|c|}{ SD } & \multicolumn{2}{|c|}{ D } & \multicolumn{2}{|c|}{$\mathbf{N}$} & \multicolumn{2}{|c|}{$\mathbf{A}$} & \multicolumn{2}{|c|}{ SA } \\
\hline & & $\mathbf{f}$ & $\%$ & f & $\%$ & $\mathbf{f}$ & $\%$ & f & $\%$ & $\mathbf{f}$ & $\%$ \\
\hline 1. & $\begin{array}{l}\text { Always to conclude an } \\
\text { idea after reading a } \\
\text { book. }\end{array}$ & 2 & 2 & $\begin{array}{l}1 \\
2\end{array}$ & 15 & 25 & $\begin{array}{l}3 \\
1\end{array}$ & 35 & 43 & 7 & 9 \\
\hline 2. & $\begin{array}{l}\text { Sharing the information } \\
\text { I get from the report } \\
\text { text/book to my friends. }\end{array}$ & 5 & 6 & 6 & 7 & 20 & $\begin{array}{l}2 \\
5\end{array}$ & 43 & 53 & 7 & 9 \\
\hline 3. & $\begin{array}{l}\text { Collecting some words/ } \\
\text { sentences I do not } \\
\text { understand from a text } \\
\text { or books. }\end{array}$ & 3 & 4 & 4 & 5 & 22 & $\begin{array}{l}2 \\
7\end{array}$ & 45 & 56 & 7 & 9 \\
\hline 4. & $\begin{array}{l}\text { Finding and using } \\
\text { techniques in reading. }\end{array}$ & 4 & 5 & $\begin{array}{l}1 \\
1\end{array}$ & 14 & 21 & $\begin{array}{l}2 \\
6\end{array}$ & 37 & 46 & 8 & 10 \\
\hline 5. & $\begin{array}{l}\text { Given a chance to share } \\
\text { their findings from } \\
\text { book/text }\end{array}$ & 3 & 4 & 2 & 2 & 25 & $\begin{array}{l}3 \\
1\end{array}$ & 43 & 53 & 8 & 10 \\
\hline 6. & $\begin{array}{l}\text { Making a group in } \\
\text { learning reading }\end{array}$ & 3 & 4 & $\begin{array}{l}1 \\
3\end{array}$ & 16 & 14 & $\begin{array}{l}1 \\
7\end{array}$ & 40 & 49 & $\begin{array}{l}1 \\
1\end{array}$ & 14 \\
\hline 7. & $\begin{array}{l}\text { Answering the questions } \\
\text { in book }\end{array}$ & 3 & 4 & $\begin{array}{l}1 \\
1\end{array}$ & 14 & 24 & $\begin{array}{l}3 \\
0\end{array}$ & 37 & 46 & $\begin{array}{l}2 \\
6\end{array}$ & 7 \\
\hline
\end{tabular}

I think it is helpful if my lecturer asks me to find and use my own technique in learning reading because I will understand more about techniques that I want to use and find out more techniques in learning reading than teacher explained it to me. (Interviewee $\mathrm{C}$ ) 
Tampubolon, Students' Perception on the Discovery Learning Strategy on Learning Reading Comprehension

Yes of course, because I think when we are provided all about the material we will be a dependent learner and I do not like that seriously. So I strongly agree if teacher involves the students in many portions. (Interviewee D)

The findings of the students' perception of the implementation of the discovery learning strategy in learning reading reveal that70\%of them agreed and strongly agreed that discovery learning strategy is a good way to be used on improving their reading skill however, $11 \%$ of them disagreed and strongly disagreed. Then, $51 \%$ of them agreed and strongly agreed and $12 \%$ of them disagreed and strongly disagreed to the item "discovery learning strategy should be used in all English reading classes". The majority 63\% agreed and strongly agreed that discovery learning strategy can be implemented in learning reading but $13 \%$ students who disagreed and strongly disagreed with this item. There were also $61 \%$ of them agreed and strongly agreed and $14 \%$ of them disagreed and strongly disagreed that discovery learning can make the students to be more active. These findings reveal that discovery learning strategy is needed by the teacher and the students in learning reading at ETSP of UKI.

Table 4

Students' Perception of the Implementation of Discovery Learning

\begin{tabular}{|c|c|c|c|c|c|c|c|c|c|c|c|}
\hline \multirow{2}{*}{ No } & \multirow{2}{*}{ Statements } & \multicolumn{2}{|c|}{ SD } & \multicolumn{2}{|c|}{ D } & \multicolumn{2}{|c|}{$\mathbf{N}$} & \multicolumn{2}{|c|}{$\mathbf{A}$} & \multicolumn{2}{|c|}{ SA } \\
\hline & & f & $\%$ & f & $\%$ & $\mathbf{f}$ & $\%$ & $\mathbf{F}$ & $\%$ & $\mathbf{f}$ & $\%$ \\
\hline 1. & $\begin{array}{l}\text { Discovery learning can } \\
\text { be implemented in } \\
\text { learning reading }\end{array}$ & 5 & 6 & 6 & 7 & 19 & 23 & 43 & 53 & 8 & 10 \\
\hline 2. & $\begin{array}{l}\text { Learning reading } \\
\text { through discovery } \\
\text { learning makes more } \\
\text { active }\end{array}$ & 3 & 4 & 8 & 10 & 20 & 25 & 44 & 54 & 6 & 7 \\
\hline 3. & $\begin{array}{l}\text { Using discovery } \\
\text { learning to improve my } \\
\text { reading skill is a good } \\
\text { way }\end{array}$ & 5 & 6 & 4 & 5 & 15 & 19 & 49 & 60 & 8 & 10 \\
\hline 4. & $\begin{array}{l}\text { Discovery } \\
\text { learningshould be used } \\
\text { in all English reading } \\
\text { classes. }\end{array}$ & 2 & 2 & 8 & 10 & 30 & 37 & 34 & 42 & 7 & 9 \\
\hline
\end{tabular}

I think yes, it is a good way. It also depends on the level. Discovery learning is a good way to improve reading skill for advanced or intermediate. However, it is not good for level elementary or beginner. (Interviewee A) 
Tampubolon, Students' Perception on the Discovery Learning Strategy on Learning Reading Comprehension

Yes of course, especially in level advanced or intermediate. So, it is a very appropriate strategy for students in the university. (Interviewee B)

Yes, In my opinion, it is a good way to use discovery learning on improving my reading comprehension because discovery learning will make me as an independent learner, it means I will solve my difficulties by myself. (Interviewee C)

Yes exactly, I think using discover learning is a good way to improve my reading comprehension because it will force me to read a book a lot, so it can improve my comprehension in reading. (Interviewee D)

\section{Conclusion}

Based on the findings data analysis and discussion, the researcher draws some conclusions. The majority of university students want to use the discovery learning strategy in learning reading because they believe that this strategy can help them to improve or develop their reading comprehension. They realize that this strategy also can make them to be more active and serious in the teaching and learning reading process. In learning reading, the students want the teachers do not spend much time in explaining reading material in the beginning of the classroom. However, they want to get much chance to practice and show their skill in reading comprehension. They are also interested in improving reading comprehension using this strategy and they hope that this strategy can be implemented in all subjects at ETSP of UKI.

\section{Suggestion}

On improving students reading comprehension, the teacher/ lecturers should use the strategy in the classroom because reading is a part of language skill which should be mastered by students in university especially in English learning filed. Because of that, the lecturers in English Teaching Study Program, FKIP- UKI should conduct discovery learning strategy in teaching reading. It will help the lecturers to enhance and build the students reading comprehension.

\section{References}

Balım, A. G. (2009). The effects of discovery learning on students' success and inquiry learning skills. Eurasian Journal of Educational Research (35), 1-20.

Bruner, J. (2006). In search of pedagogy. London: Routledge.

Cameron, L. (2001). Teaching language to young learner. Cambridge: Cambridge University Press. 
Tampubolon, Students' Perception on the Discovery Learning Strategy on Learning Reading Comprehension

Grabe, W., \& Stoller, F. L. (2013). Teaching and researching reading. London: Routledge. Hammer, D. (1997). Cognition and instruction. London: Routledge.

Hoffman, S. K. (2013). Instruction for discovery learning: Levels of implementation exhibited

a sample of algebra I teachers (Unpublished Master Thesis). Texas: Faculty of the Graduate School of the University of Texas.

Larsen-Freeman, D. (1990). Language teaching methods: Teacher's handbook for the video series. Washington: U.S. Department of State.

Mahmoud, A. K. (2014). The effect of using discovery learning strategy in teaching grammatical rules to first year general secondary student on developing their achievement and metacognitive skills. International Journal of Innovation and Scientific Research, V(2), 146-153.

Grabe, B. 1997. Discourse analysis and reading instruction. In Functional approaches to written text: Classroom applications, ed. T. Miller, 2-15. Washington, DC: United States Information Agency.

Pardede, P. (2008). A review of reading theories and its implication to the teaching of reading. Retrieved from https://parlindunganpardede.wordpress.com/articles/ language-teaching/a-review-on-reading-theories-and-its-implication-to-theteaching-of-reading/

Pardede, P. (2007). Developing critical reading in the EFL classroom. Retrieved November 2013 from http://parlindunganpardede.wordpress.com/articles/ language-teaching/developing-critical-reading-in-the-efl-classroom/

Rahmi, Y., \& Ratmanida. (2014). The use of discovery learning strategy in teaching reading report text to senior high school students. Journal English Language Teaching, III (1), 179-188.

Saritas, T. (2005). Cost and benefits of guided discovery architecture online programs. The Turkish Online Journal of Educational Technology, IV (3), 54-67.

Tarigan, H. G. (1987). Membaca sebagai suatu keterampilan berbahasa. Bandung: Angkasa. 